\author{
Leszek Leszczyński \\ Maria Curie-Sklodowska University \\ Lex525@wp.pl
}

\title{
Types of Application of Law and the Decision Making Model
}

\author{
Typy stosowania prawa a model procesu decyzyjnego
}

\begin{abstract}
This article is aimed at associating particular types of application of law, as defined by legal theory, with the decision making model of the process of application of law. Although the model is built on the characteristics of the judicial type of decision making, it also includes important features of other types of decision making processes. The features pertain to, in particular, the subject and the mode of the process as well as decisions, types of control over decisions and decision making discretion. The decision making model is constructed in two versions: the basic version (that ends in making the decision on the consequences of the normative qualification of the facts) and the broad version (encompassing control and enforcement proceedings). Particular components of each version of the decision making model include both validation and reconstruction of the normative basis of the decision on the application of law. These components occur simultaneously and in sequence. Apart from these components, the versions also include establishing the facts, reasoning and the activities of operative interpretation. The versions are subsequently translated into argumentation expressed in the form of justification of the decision to apply law (also a component of the decision making model). Such argumentation is formulated in different styles and refers in different ways to the contents of the decision and to the rationalisation of the process.
\end{abstract}

Keywords: types of application of law, decision-making model, operative interpretation

\section{TYPES OF APPLICATION OF LAW}

\subsection{The judicial type versus non-judicial types}

The division of decision making in application of law into different types may be presented in a relatively simple manner, by dividing it into the judicial and nonjudicial type. The singular used for each type may breed questions. However, at this stage of analysis, adoption of this dual division may constitute a good point of departure. 
The judicial type is not subject to any doubt as this type is the model type of application of law. This pertains to, in particular, the contemporary legal orders, where the scope of judicial decision making is becoming broader, and judicial control encompasses different type of decision making in different cases. Additionally, such cases at times adapt, to a larger or smaller extent, to some characteristics of the judicial decision making model. This is not affected by the possibility and purpose of definition of certain subtypes of the judicial application of law, based on statutory procedural regulations developed in advanced legal orders. Such regulations include the classic procedures such as civil and criminal procedures, as well as administrative, constitutional, inter- and transnational court proceedings established in the $20^{\text {th }}$ century. ${ }^{1}$ Regardless of the particular differences between the types of procedures, both the rules and the practice of judicial decision making shaped by these rules contain a range of the same or similar characteristic features that facilitate their classification as one decision making type.

Important issues and certain doubts surface when we differentiate the nonjudicial decision making types. Here, the key is not to specify the relevant procedural regulations of the proceedings but rather the different types of the decision making process and decision making itself.

Of the non-judicial types, the process of the administrative type of decision making does not raise many doubts. This process is based on a separate procedural regulation (e.g. Code of Administrative Procedure ${ }^{2}$ ), and even if the regulation has its mutations in the form of separate comprehensive regulations (e.g. Tax Ordinance $\mathrm{Act}^{3}$ ) or certain specific regulations (e.g. procedural regulations present in the legal-substantive regulations of construction $\operatorname{law}^{4}$ ), it still shares rules of procedure in the decision making type that stem from the Administrative Procedure Code.

The question of separation of the managerial type (subtype ${ }^{5}$ ) remains open. The key features of this type are a combination of the features of decision making in the administrative procedure with special features of the practice of management of an organisational entity or, in a broader sense, a defined and separate area of reality. A way to resolve the issue could be a separate administrative-managerial type. However, if this type were to be applied, we would have to specify further if the type replaces the administrative part or is complementary to the administra-

${ }^{1} \mathrm{Cf}$. articles in part 2 of this volume.

${ }^{2}$ Act of June 14, 1960, the Administrative Procedure Code (i.e. Official Journal of Laws No. 98/2000, item 1071 with further amendments).

${ }^{3}$ Act of August 29, 1997, the Tax Ordinance Act (i.e. Official Journal of Laws No. 8/2005, item 60 with further amendments).

${ }^{4}$ Act of July 7, 1994, Construction Law (i.e. Official Journal of Laws No. 207/2005, item 2016 with further amendments).

${ }^{5}$ Cf. W. Lang, J. Wróblewski, S. Zawadzki, Teoria państwa i prawa, Warsaw 1979, pp. 412-413. 
tive type. Another attempt at resolving this issue - one that seems quite apt - is to keep the administrative type as the key non-judicial type, with the managerial type defined as a subtype of the administrative type. Alternatively, in a softer version, managerial elements can be recognized in the administrative-managerial type through decisions to apply law made within the administrative-managerial type.

Another issue, very significant from the perspective of the current (both global and Polish) tendencies in dispute resolution and allocation of legal rights and obligations, is the separate nature of the mediation-negotiation type (subtype) of application of law. ${ }^{6}$ We must first answer the question whether such a type is indeed a type of application of law (making the decisions to apply law), whether the reasoning and argumentation (e.g. in the form of justifications of decisions) characteristic of application of law is present in such activities, and whether a decision with contents resulting from mediation constitutes a decision to apply law. Positive answers to the above questions will enable us to proceed to define the character and the scope of separateness of the type (subtype) of decision making (perceived as a different decision making technique, in particular a different technique of developing of the content of the decision). Such answers will also enable us to define this type's relation to the judicial and administrative types (as in the latter, elements of mediation and bargaining are present and play an increasingly important practical role ${ }^{7}$ ).

For the purposes of this volume and in the context of further contrastive analy$\mathrm{ses}^{8}$, we may assume the grounds for distinguishing the two basic types (judicial and administrative) and the two special or derived types (managerial and mediation).

\subsection{Basic differentiation criteria}

The division into the judicial and non-judicial types presented above and the question of differentiation of types of application of law indicate the importance of the criteria that are fundamental for both the basic and the specific differentiation.

The most fundamental criterion is the type of the subject making the decisions to apply law within the given type. In the judicial type, the subjects are the courts, both general and special (e.g. constitutional or administrative), while in

${ }^{6} \mathrm{Cf}$. articles in part 2 of this volume. Cf. also: A. Kalisz, A. Zienkiewicz, Mediacja sadowa i pozasadowa. Zarys wykładu, Warsaw 2009, p. 15 and further pages; Z. Kmieciak, Mediacja i koncyliacja w prawie administracyjnym, Cracow 2004; J. Harczuk, Uzgadnianie w stosowaniu krajowego prawa publicznego, particularly chapters 1-2, Lublin 2009 (unpublished $\mathrm{PhD}$ dissertation).

${ }^{7}$ Cf. e.g. art. 10, 183-186 of the Administrative Procedure Code, art. 23a Criminal Procedure Code, art. 115-118 Act of August 30, 2002 - Law on Proceedings before Administrative Courts (Official Journal of Laws No. 153/2002, item 1270 with further amendments, hereafter referred to as the "p.p.s.a", articles 114-122 of the Administrative Procedure Code).

${ }^{8} \mathrm{Cf}$. articles in part 2 of this volume, in particular by A. Szot and M. Myślińska. 
the administrative type the subjects are public administration bodies which can be subdivided further (into general, specialised, central and local, central government and local government, etc.). For the managerial type, the subjects are managers of particular organisational units (workplace managers) or managers of particular spheres of reality/activity (e.g. decisions made by prosecutors). The subject, however, does not explain the foundation of a complete catalogue of activities for the corresponding type and does not encompass (for the judicial type) e.g. decision making in independent arbitration (various mediation proceedings) or decision making implemented by disciplinary committees whose activities are in alignment with other features of the judicial type.

Differentiation of subjects that apply law is associated with the positioning of the subjects within the network of state institutions and towards the addressee of the decision. This, in turn, is associated with the assignment of particular characteristics to the subjects - the characteristics that define the mode of decision making. This concerns predominantly the characteristic feature of the judicial independence (including court, judges but also mediators and arbitrators) and the lack of any professional dependence between the deciding party and the addressees of the decision who could potentially influence the independent nature of the judicial ruling. In the administrative type, the activities performed are not characterised by independence. However, the feature of independence, although it is sometimes present (as in the activities performed by prosecutors or by self-government courts of appeal) is limited due to the obligation to implement a certain policy and due to their accountability for the performance of specific tasks. Within the managerial subtype the latter attributes are particularly powerful in certain managerial activities, as they are linked to the expectation of efficiency and effectiveness in the management of an organisational entity and persons (employees) subordinate to the decision maker. It is also the case in the basic administrative type that subordination of the recipients of decisions to the decision maker is usually not an obstacle to the decision making process, unless there is a personal relationship between the parties.

What is shared by all the types of application of law is the typical presence of authority-based activities of decision making entities. However, we also see certain differences. If we assume that based on the model, the authority of a lawapplying body to make all types of decisions is a defined authority (subject matter, time and place jurisdiction), this attribute is to be strictly linked with the judicial type and the mediation type. In the administrative type, in turn, the basis for action may sometimes be based on general authority, resulting for example from task-based norms. This pertains in particular to certain activities present in the managerial type, whereby a manager of a workplace is guided by his/her general task to efficiently and effectively manage the company while treating legal norms 
(also the internally binding company norms) as a framework within which his/her tasks are to be implemented.

A significant differentiating factor for the types of application of law is the mode of initiation of the decision making process. While the attribute of the judicial type (and mediation proceedings) is initiation upon an external trigger (lawsuit, indictment, complaint, motion for declaration, etc.) and thus may be perceived as a reaction to the external stimulus (time passing is also potentially such a trigger). Such a reaction leads to legal qualification of the claim and the facts it describes. By contrast, in the administrative and managerial type, the decision making process may be initiated both externally (typically - by the recipient of the decision) and internally, at the decision maker's own initiative (ex officio), as a result of performance of a certain task. The task is usually associated with a politically grounded vision of changes to the particular sphere of reality that result from the intervention (this does not exclude the possibility of using external information that does not constitute a formal claim or application). If an administrative body is acting at its own initiative, which is particularly characteristic of the managerial type, the key is not to qualify the accomplished facts but to assess in an anticipatory way the utilization of the facts as defined by law for the accomplishment of the planned goals and tasks (e.g. expropriation from real estate based on statutes and local planning schemes for construction of public roads).

The character of the decision making process may be associated with the existence or non-existence of a legal dispute at its root. The aim of the process is resolution of the dispute in the form of qualification of facts and definition of the relevant legal consequences. The existence of the dispute is a condition for mediation proceedings and is typical for the classic judiciary type. It can take the stronger form (classic contradictory type) and the weaker form (with elements of inquisitiveness). However, within judiciary proceedings, the existence of dispute is not a condition as the object of judiciary decision making may be the issues of definition of law or legal status, or updating of laws or obligations. This occurs in non-contentious proceedings. Such non-contentious proceedings processes may often transform into contentious ones if certain elements appear. It must be noted that the contentious type does not occur in the managerial type of application of law, within which questioning of the contents of the decision by its addressee usually leads to disputes resolved by courts. The classic administrative type is also normally non-contentious, although dispute elements do occur in contemporary practice (e.g. in the form of administrative hearings). Thus, they influence the changes in perception of administrative proceedings, even though the scope of contradiction is not comparable to the one present in the judicial type.

The types also differ in the modes of ending of the decision making process and their components. As a rule, all decisions concerning application of law are decisions of individual and particular character. In rule of law, this applies without 
exception to the judicial, mediation and the classic administrative types. It is only the managerial type that includes certain particular and collective decisions (pertaining to, for example, particular behaviours of all persons who are employees of the company at the given point in time). Such decisions may not be generally binding norms. The decisions take different names and forms: sentences, decisions, rulings, regulations, resolutions, orders etc. and they are normally associated either with one type (e.g. sentence, administrative decision) or with different types of decision making. In their model version, they require the written form. In contemporary legal orders they also require a justification, either oral or in writing. Within the judiciary type the justification is or is not conditioned by filing a separate claim, while in the administrative type it is formulated ex officio, with the exceptional possibility of derogation. ${ }^{9}$

Decisions to apply law are in contemporary legal orders subject to control, whether justified or not (although the presence of justification makes the control more complete and more efficient). Both basic types have the same and different forms of control over decisions. In both we deal with control at different levels (instances) - there are different types of appeals or applications for judicial review undertaken within the judicial and administrative "silos" (in this context, a single instance is possible in the mediation type of decision making). In both basic types there is also the element of social control at different institutional or organisational levels that surfaces in particular when socially "sensitive" decisions are made (i.e. important or highly publicised decisions). A variation of this type within the judicial type is the "professional" control expressed in doctrinal commentaries or interpretations of legal doctrines. Within the administrative and managerial types there additionally exists the external judicial control (in administrative courts or general courts, also regarding mediation proceedings) and political control (assessment by the "superordinate" or a centre of political power based on the criterion of fulfilment of the goals and tasks of the decision maker).

\subsection{Types of decision making processes versus decision making discretion and policies of application of law}

The existence of decision making discretion (freedom of decision making) is the universal feature of activity within all types of decision making processes. Such discretion is of "natural" origin as it stems from the lack of clear-cut linguistic boundaries of the legal texts that constitute the source of reconstruction of the applied legal norm, the character of the process of application of law that materializes the interpreted general norm in the context of the unique factual state and changeable social reality where the decision to apply law is made based on a rela-

${ }^{9} \mathrm{Cf}$. art. $107 \S 4$ of the Administrative Procedure Code, indicating such possibility in the case of complete admission of the party's claim, when there are no conflicting interests of the parties and the decision is not issued as a result of an appeal. 
tively unchangeable legal text and legal system. Decision making discretion is also an expression of the relevant lawmaking policy (lawmaking will) expressed at the framework level of the normative regulation and in special constructs that "open" the system of normative regulation (general renvoy clauses, non-specific statements, grounds for discretionary decisions). This results in broadening the scope of discretion based on natural sources.

Thus, a situation of striving towards maintenance of pragmatic alignment between the value of legality and the virtue of flexibility of application of law comes into play, expressed in the maintenance of the appropriate proportions between compliance of the decision with stricti iuris norms and the fulfilment (thanks to decision making discretion) of the open criteria of equity, and, in the administrative type of political purposefulness. The axiological complex pertaining to the practice of application of law also encompasses other values. On the one hand, these values appear in the complex relationship between rule of law and justice, and on the other hand, in the value/virtue of certainty, homogeneity and effectiveness of application of law (which, within, the mediation subtype seem to independently fulfil the criteria of "legality"). In order to assess the presence and role of the decision making discretion it is crucial to notice the contribution of the discretion to building the right proportions between legality and flexibility of application of law. This is the case when the discretion is intended (consciously implemented), has directed content (if we deal with purposeful discretion), is openly disclosed and based on the right anticipation of impact (associated with minimal side effects) and controlled (predominantly in the process of supervision by instances).

The occurrence of decision making discretion has a number of justifications in the doctrine. For judicial decisions the justification is the so-called bound decision, free decision and lawful and rational decision theories. For decisions made within the administrative type, the catalogue of such ideologies may include bureaucratic, technocratic, democratic or politicised style of decision making. ${ }^{10}$

The processes of making decisions to apply law also call for the issue of the policy of application of law. In particular, the question is whether we can talk about policy as a "practical concept" pertaining to the process of application of law. Based on the relevant Polish literature, the "practical concept" refers also, in Leon Petrazycki's interpretation, to the separate science of the policy of law. ${ }^{11}$ This would include the formulation of the objectives, principles and measures forming the basis for implementation in the context of the tasks of decision mak-

${ }^{10}$ Cf. J. Wróblewski, Sądowe stosowanie prawa, Warsaw 1988, pp. 383-396; L. Leszczyński, Zagadnienia teorii stosowania prawa. Doktryna i tezy orzecznictwa, Cracow 2000, pp. 40-41.

${ }^{11}$ Cf. L. Petrażycki, Wstęp do nauki prawa i moralności, Warsaw 1959, pp. 13-14; idem, Wstęp do nauki polityki prawa, Warsaw 1968, passim, in particular pp. 25-66. See also: A. Podgórecki, Założenia polityki praw, Warsaw 1957, passim. 
ing entities. This, in turn, would translate into the content of decision making practice and, directly, on the content of particular decisions to apply law.

It seems that the answer to the questions posed above should be associated with the division of the particular types of application of law as presented at the beginning of this monograph.

The principle of the independence of the judiciary means that the in a lawful state the possibility of appearance of a law application policy, referred to as "doing justice", originating from a political decision making centre and directed towards independent courts in a lawful state is not justified, even if the effects of such policy do not influence the content of particular decisions made within the judicial or mediation type. Influence on the content of judicial decisions within the judicial decision making type may only be effected through legislation. Certain "agreed practice" may, however, appear within this decision making type as a result of precedent of more or less precisely defined ruling tendencies, usually resulting from decisions made by the highest courts of appeal. Still such "agreed practice" does not equal direct impact on particular decisions (unless such impact results from the contents of resolutions made by full court that are binding for regular court or from the effects of decisions by lower courts having been repealed, this being a direct jurisdiction rather than political measure). Moreover, in lawful states, it does not include suggestions resulting from the will of political centre (the "political nature" of ruling and judicial decision making may, however, be associated with defining efficient and effective judicial reactions to certain social phenomena in the form of e.g. specification of the mode of defining the normative consequences within the decision making discretion).

In turn, law application policy exists in the administrative and managerial type. It does not constitute a violation of the principle of rule of law if it fits within the boundaries of law (i.e. it does not lead to violation or bending the law) and refers to defining the "decision making strategies" while not influencing the content of any particular administrative decision in a direct way. It is associated with utilization of decision making discretion, including the discretion associated with the construct of administrative recognition. Political directives within such administrative decisions may stem from political power centres (both central-level and local) or superordinate bodies (in the case of the managerial types - from the entity's supervisory body). This impact may be limited by the presence of the appropriate control procedures (the most important of which are judicial control performed in particular by administrative courts that can focus on aspects of political impact from the perspective of compliance with $\mathrm{law}^{12}$ ) or on the model exemption

${ }^{12}$ Cf. M. Jaśkowska, Uznanie administracyjne w orzecznictwie sąów administracyjnych, ,Zeszyty Naukowe Sądownictwa Administracyjnego" 2010, No. 5-6, p. 168 and further pages; L. Leszczyński, Orzekanie przez sądy administracyjne a kontrola wyktadni prawa, „Zeszyty Naukowe Sądownictwa Administracyjnego" 2010, No. 5-6, p. 267 and further pages. 
of particular decision making mode from the linear and direct political or organisation subordination (which is the case in self government appeals courts). This is shown in the particular types of activities in different ways, within the boundaries of a certain scope of autonomy of the decision maker (e.g. specific constructs of independence and subordination in the prosecution service). The existence of control mechanisms limits the directness and specificity of political influence. Yet the political influence, as a rule, cannot be totally eliminated from the circumstances of defining and implementation of social policy - particularly in an "active" state (or even an "merely intervening" state). This means that associating the notion of policy of application of law with these decision making types is justified.

\section{THE DECISION MAKING MODEL OF THE PROCESS OF APPLICATION OF LAW}

\subsection{Models of the process of application of law}

It seems possible to refer all of the above-mentioned types of application of law to the catalogue of models built in the Polish literature by J. Wróblewski for judicial application. ${ }^{13}$ The catalogue encompasses, on the one hand, descriptive models (presentation of the process and the decision to apply law) as well as normative models (that indicate the postulate image of the decision making process). The former type may have a descriptive-generalisation dimension (generalising empirical material) or a theoretical dimension (resulting from higher level theories, e.g. the theory of information processing). The latter, in turn, may be constructed on the grounds of existing law or on the grounds of the adopted concept (ideology) of the faultless decision making process. Within the descriptive models we can distinguish: (1) the decision model that relates to application of legally substantive or procedural regulations that define the decision maker's activities within the proceedings of one or more instances, (2) the information model that presents application of law as information processing and (3) the functional model that treats application of law as an element of social control exercised by law.

Despite these differences that enable us to see different characteristics of the two basic types (judicial and administrative) and the subtypes (mediation and managerial), all of the models of application of law indicated above may in principle be referred to the general characteristics of the decision making process, to a large extent independently from the characteristics of the particular types of application of law (apart from the procedural model that is constructed based on specific regulations of particular types of judicial and administrative proceedings). This shows a universal nature of the legal decision making processes (also including legislative decision making that is beyond the scope of this article) as

\footnotetext{
${ }^{13}$ Cf. J. Wróblewski, op. cit., p. 24 and further pages.
} 
far as their activities and the preceding reasoning are concerned. This extends to other types of social decision making beyond the legal type (e.g. decisions regarding investment, professional and career-related decisions, personal life decisions, etc.), of course with different "normative groundwork" and different, relevant consequences of such activities.

In the following part of my monograph the subject of analysis of activities and reasoning will be the decision making model categorised above as the descriptive model. J. Wróblewski defines the dependency as a descriptive-generalising approach that is based on emphasizing the elements from substantive law that influence the definition of contents of the decision and that may appear in the justification of the decision. ${ }^{14}$

Taking into account the above categorisation and differentiation we must note that the decision making trait of the model refers to what J. Wróblewski defines both as a substantive decision making model ("application of specific substantive law provisions" that set the possible legal consequences of the facts deemed proven ${ }^{15}$ ) and, to a certain extent, as a procedural decision making model. ${ }^{16}$ In the substantive dimension of the decision making model the modification of the approach presented above consists in, above all, counting not only provisions of law but also other decisions to apply law (precedents) and other non-legal criteria as sources of definition of the contents of the decision. As far as the non-legal criteria are concerned, they are referred to by the provisions of law. Moreover, decisions are perceived not as consequences of facts deemed proves but as consequences of the the qualification of the relevant statement of fact. As far as the procedural dimension of the model is concerned, it will be crucial for the analysis to not only distinguish the level of the basic instance and control instances, but also, equally crucial, the process of the core decision making and the executive decision making. The latter differentiation may be presented as the basis for discerning a number of decision making models, but also as a basis for building one comprehensive decision making model that refers to application of legal substantive norms on the grounds of procedures that facilitate both control and executive levels of decision making.

The decision making model discussed below is therefore a universal model to the extent that does not call for reference to particular procedural regulations. Despite the descriptive grounding of the model, it will not entirely avoid the indication of legal aspects of the normative model, but it will not indicate particular regulations: instead, it will refer to cultural and legal circumstances within which the decision making processes are taking place.

\footnotetext{
${ }^{14}$ Cf. ibidem, pp. $42-43$.

${ }^{15}$ Cf. ibidem, p. 42.

${ }^{16} \mathrm{Cf}$. ibidem, p. 49 and further pages.
} 


\subsection{Components of the decision making model}

The decision making model proposed here and aimed at defining the essence, the key components (activities and reasoning) and the course (phases) of decision making process for application of law is based on discerning the two key phases and two additional phases that can be treated as separate decision making processes. The first two phases (the key phases) create the totality of the basic model ending with a decision, although, from the procedural standpoint, the decision is not a legally binding nor an executed decision. In this context, the decision making model presented here also takes into account certain procedural aspects that influence, among others, the definition of the scope of decision making process.

In the key or fundamental process of decision making it is important that we distinguish the preparatory phase and the decision formulation phase. The phased nature means that preparation precedes the actual decision making. This, however, does not mean than proceeding to the formulation phase excludes the possibility of retracting to certain activities and reasoning from the preparatory stage. Returning to the preparatory phase may establish anew the substantive groundwork for the decision to apply law. Within the model, however, it must be assumed that performance of all activities from the preparatory phase facilitated passing to the formulation of the decision to apply law.

The preparatory phase includes two types of activities and their corresponding reasoning types: stating the facts and defining the legal status.

These activities cannot be framed into a phased process as they overlap and occur both simultaneously and sequentially within the process of application of law, possibly in a much clearer way than in other decision making processes (e.g. in the process of lawmaking). Apart from the initial stage of this phase when the decision maker learns about the facts in the statement of facts from the point of view of the initiator of the decision making process, the finding of legal basis (identification of sources and reconstruction of the relevant norm) is of simultaneous nature than happens in sequences reflecting the significant component of the facts of the given case. In the following phase (the decision making stage) the discovered legal bases will facilitate qualification of facts and, assuming gradual substantiation, definition of normative consequences of the qualification of facts. The simultaneous nature, however, does not mean that each individual fact-finding is also finding of its legal status but that it only occurs in relation to homogeneous facts (sometimes only for a unique, exceptionally important fact) that are significant for the entire factual picture. The sequentiality contained within the process therefore includes both the definition of actual facts and the legal status. There is also the possibility of returning to the already defined legal findings whenever there is a new, significant fact or group of facts of the case. It follows therefore that although the description of legal status is, as a rule, a reaction to fact finding, it must be assumed that the two are non-symmetrical but still simultaneous. This 
is so especially due to the fact that we cannot exclude a situation where some legal findings concerning one type of behaviour based on the relevant fact-finding lead to the necessity of investigating new factual components.

Both types of activities differ in the character and the underlying type of reasoning. As fact finding is an activity of cognitive character, regulated legally and containing elements of the so-called formal truth that is not entirely subject to the realistic approach of "substantive" truth. ${ }^{17}$ In contract, the activities of defining the legal status are based on operative, sensu largo interpretation of law, that includes (in the validation/derivative approach) the finding of the source of reconstruction of the norm applied and the reconstruction of the norm itself that later in the process becomes the normative foundation of the decision to apply law i.e. the competence-based, procedural and legal-substantive foundation.

According to the model, reconstruction of the normative basis of the decision ends the preparatory phase, within which no final decision has been made. However, partial decisions within the process have been made, regarding fact finding, the source of reconstruction and the normative basis of the decision. This leads to the subsequent phase of formulation of the decision to apply law. The decision to apply law may be described either as two separate decisions in terms of their contents (for praxeological reasons) or in the form of one decision with two components (for procedural reasons). The first component (or the "first" separate decision) is the normative categorisation of the facts that consists in reducing the contents of the legal substantive norm (resulting from the definition of the relevant legal status). The norm contains the exemplary pattern of behaviours for regular recipients of decisions, including the relevant recipient. The second component (or the "second" decision) is finding the legal consequences of the categorisation of facts. This consists in reducing the relevant contents of the legal substantive norm to the results of the categorisation. Distinguishing both components of the final decision facilitates relating both reduction to the theoretical concept of the sanctioned and sanctioning norm. ${ }^{18}$ As the norm does not only lead to application of classic legal sanction but can also lead to the arrangement consequences other than sanctions (in the form of definition of legal status or authority/obligation update), it seems to be a better choice to call it a consequential norm. Reduction of the legal substantive norm as the normative basis of the decision would mean, in this approach, the reduction of, respectively, the sanctioned norm (categorising norm) and sanctioning norm (the consequential norm).

Making the decision to apply law that defined the legal consequences of the established facts ends the basic decision making process but it does not end the

${ }^{17}$ Cf. M. Zieliński, Poznanie sądowe - poznanie naukowe, Poznań 1979, particularly p. 187 and further pages.

${ }^{18}$ Cf. J. Lande, Studia z filozofii prawa, Warsaw 1959, p. 925 and further pages; Z. Ziembiński, Problemy podstawowe prawoznawstwa, Warsaw 1980, pp. 159-160. 
case investigated by the process. This is so due to the possibility of an appeal that "launches" a new, separate decision making process. The new process typically includes all the phases and activities described above as well as reasoning types of the basic process while retaining the relevant separate elements of fact finding in the appeals procedure (dependency on the type of appellative measure) or the normative categorisation of not only facts sensu stricto but also legal facts in the form of the relevant ruling or administrative decision (e.g. in cassation procedure). Treating the appellative process as a separate decision making process from the authoritative and procedural perspective does not exclude the possibility of treating the same process as the next phase of the decision making process, ending with another final decision or decision triggering final decision (in the case of submission for review and remand). This, in turn, may trigger another inter-instance decision making sequences that need to proceed and finish before the initial case is finally resolved.

Similar remarks may pertain to the decision making process, the subject of which is execution of the decision made in the basic or appellative process. Treating the executive decision making process as a separate process is particularly well-grounded for to authoritative and procedural reasons. This is so not only because such processes are normally subject to separate procedures ${ }^{19}$ but also because their course may trigger further basic processes that occur, as it were, "accidentally" (e.g. in the case of judicial control of decisions by administrativeexecutive bodies). However, perceiving the appeals process as another phase of the decision making process must mean the same in the case of the enforcement process. This means that the decision making process is not actually complete before the enforcement process finishes. This applies particularly when the decision making process is perceived from the perspective of the recipient (not only the direct one, but also indirect ones), the decision to apply law that establishes the legal consequences of the facts for whom the decision making process is completed when full execution of the contents of the consequential decision takes place.

\section{OPERATIVE INTERPRETATION IN THE DECISION MAKING MODEL}

\subsection{Components of operative interpretation: the validation-derivative approach}

Reasoning and interpretative activities undertaken in the process of operative interpretation are components of the process present in each of it sequences (in

\footnotetext{
${ }^{19}$ As defined in the relevant normative acts Act of June 17, 1966, the Administrative Procedure Code (i.e. Official Journal of Laws No. 207/2005, item 1954 with further amendments, Act of June 6, 1997, the Executive Penal code, Official Journal No. 90, item 557 with further amendments) or in separate parts of code regulations (e.g. part 3 of the Administrative Procedure Code).
} 
the sensu largo approach). Operative interpretation is understood here as practical (decisional) interpretation that is implemented in the decision making process of application of law. ${ }^{20}$ Compared against other types of legal interpretation (authentic, legal, delegates or, in particular, doctrinal interpretation which has no direct practical importance ${ }^{21}$ ), we clearly see, firstly, the decision-related perspective of the interpretation, undertaken and managed in order to make a decision to apply law. Secondly, we see the certainty of arriving at an outcome of the interpretation that can be operationalised and that results from the procedural obligation to make the decision to apply law. Thirdly, we observe the "situational" nature of interpretative reasoning, whose contents are dependent on the simultaneous fact finding. Fourthly, we see the limited scope of the interpretation that finally leads to reconstruction of the "norm to be applied" (i.e. normative basis of the decision of application of law in the particular decision making process) rather than the "complete norm". The former is subsequently reduced to the contents of the decision to apply law.

Interpretative reasoning occurs within the decision making process as a component of definition of legal status where the reasoning constitutes the core that is later "reduced" to the contents of the categorising and consequential decisions. It also occurs within fact finding if the process of fact finding is dependent on the normative regulation of issues such as the catalogue of admissible pieces of evidence, the principle of free assessment of evidence, evaluation of facts by the norm etc. This is visible above all in the case of reconstruction of the relevant categories of procedural norms.

Interpretative reasoning as a component of decision making process must be described in a broad enough (holistic) manner in order to include not just the normative reconstruction of the basis of the decision and validation findings, but also the so-called "pre-reconstructive intuitions". The intuitions occur before precise validation and reconstruction, and include the impressions and associations of the interpreter. Such impressions and associations result from the "first sight" at the material of the case that is the subject of the decision making process. The are realized through a lack of doubts (not always consciously perceived as a separate reasoning) as to whether the case has a legal status and "deserves" protection (the systemic and axiological argument), possibly associated with more complex interpretations of the meaning of the words describing the subject of the case (the semantic argument), or the authority-based basis of activity (which can re-direct the interpretation to a different "preliminary" route leading to the entire operative interpretation). ${ }^{22}$

${ }^{20}$ Cf. L. Leszczyński, Wykładnia operatywna (podstawowe właściwości), „Państwo i Prawo” 2009, No. 6, p. 11 and further pages.

${ }^{21}$ Cf. M. Zieliński, Wybrane zagadnienia wykładni prawa, „Państwo i Prawo”, 2009, No. 6, pp. 3-10.

${ }^{22}$ Cf. L. Leszczyński, Zagadnienia teorii stosowania prawa ..., pp. 116-117. 
Validation findings sensu stricto mean, within the operative interpretation, the definition of a catalogue of sources of normative reconstruction of the basis of the decision to apply law. This reasoning is well grounded in the cultural features of the given legal order, yet it is associated with declaring both model and concrete (within the given decision making process) role of the sources that are not, in this case, primary sources. In statutory legal cultures where normative acts of law with legal provisions are the primary source, this pertains to the possibility of inclusion of earlier decisions to apply law to this catalogue (as precedents they are primary sources in the common law culture) as well as extra-systemic criteria (primary sources for different types of equity-based rulings) and the definition of the relationship between the "additional" sources and the primary sources.

Inclusion of validation findings into operative interpretation enables us to notice the dependencies important for the outcome of the decision making process i.e. the dependencies between the findings and the reconstruction of the applied norm itself. Although this activity typically precedes reconstruction, these findings facilitate verification of the catalogue of sources until the end of the reconstruction process - if the newly-established facts require such verification. Although the dependency described above is potentially to be encountered in each interpretative process, in some of its types (e.g. if there are conflicting findings or inferences) it cannot be avoided as the reconstruction of the normative basis of the decision is intertwined with validation findings, with the latter being decisive as to the applicability of the given source within the decision making process.

Operative interpretation also includes the reconstruction of the normative basis of the decision (understood as authority basis, procedural norms and legal substantive norms) from the sources included to the catalogue of sources after validation as well as the reduction of the normative basis that maps the result of the reconstruction onto factual findings in the context of definition of the content of the decision that qualifies the status and sets forth the normative consequences of the qualification.

There is neither enough space in this monograph nor any particular need to define the rules (directives) of reconstruction, whose catalogue is associated with discerning linguistic principles (semantic and syntactic), systemic-structural principles, systemic-axiological principles, purpose-related principles, functional principles and the principles open axiology. Although the relationship between particular principles are typically based on the assumption of primary role and importance of linguistic and systemic principles for the interpretative outcome, they depend in details on many factors. These factors include: type of legal culture, type of political system and juridical factors such as branch of law, instance of the decision making entity or types of decision making process as specified above.

The components of operative interpretation in the scope described above appear in all decision making types and include both basic and control as well as 
executive decision making processes (phases of decision making process). In the case of control processes, the location of fact finding may be different but control always encompasses the process of operative interpretation, covering in some types of control proceedings (cassation sensu stricto, control of compliance of legislation with the constitution, judicial control of administration) the totality or almost all sorts of reasoning in the decision making process. Also, in executive processes (phases), operative interpretation takes analogical position as in the primary processes, thus leading to the decisions relevant for such processes.

\subsection{Interpretative argumentation in justifications of decisions to apply law}

Regardless of the fact whether the justification of the decision to apply law is formulated orally (provision of motifs) or in writing (with different requirements in different types of application of law and types of procedural regulation $^{23}$ ), the subject of such justification includes all components of the decision making process. In particular, the arguments provided in the justification refer to the established facts and legal status. The key component within the legal status is broadly understood operative interpretation. A validation-derivative approach to the interpretation enables us to take into account both the findings pertaining to the sources of reconstruction and the reconstruction of the very normative basis of the decision. The interpretation also occurs when providing arguments pertaining to the established facts, that typically rely on the "reality-truthful" criteria but also include the reconstruction of norms that regulate elements of the formal truth.

The content of justification of decision of application of law includes the "legality" arguments that refer to the basis of authority (decision maker's legitimacy), procedural bases of activities (legality of the decision making process) and legal substantive bases (legality of the contents of the decision) as well as contentbased arguments that refer to accuracy (truthfulness) of the established facts and to accuracy of the contents of the decision, including the arguments for the decision's content's rational merit, functionality or legitimacy (within the axiological argumentation with different sources).

The above-mentioned arguments may be provided in different manners that are typically clearly discernible in more extensive written justifications. In this context, alternative modes of formulation of contents of justification must be mentioned. They can take the form of a description of the implemented reasoning and activities or their rationalisation (or a combination of the two), which opens up the issue of exclusivity of each argument and of any possible relations between

${ }^{23}$ Cf. art. 328 of the Civil Procedure Code, art. 424 of the Criminal Procedure Code, art. 141 of the Act on Administrative Courts Proceedings, or art. 107 of the Administrative Procedure Code. 
the arguments. It seems reasonable to assume that in reality, both types of arguments occur in justifications. They occur in different proportions, depending on the justifying subject (an in particular - the subject's instance), the type of application of law, the branch of law and the type of social environment of the law (type of political system, social change, etc.) - with the assumption, however, that the descriptive elements within the justification serve the rationalising argumentation that is to eristically convince the recipient of the justification.

Arguments within the justification can be formulated in different presentation styles (different structure of the contents of the justification) that are referred to and described in literature, e.g. deductive style vs. discursive style, or legalistic style vs. substantive style. ${ }^{24}$ It seems that the deductive and legalistic elements correspond to arbitrary style, as opposed to the discursive style. In legal orders based on statutory law, the arbitrary style is based mainly on legal provisions that are interpreted in a way that leads to indicating the decision as the only possible outcome of reconstruction of the normative basis of the decision from the provisions. Thus, indication of the decision as the best possible choice is avoided, and so is the authorship of the contents of the decision: the de-personification occurs through avoidance of inclusion of one's own views and ideas in the argumentation. By contrast, it is precisely the expression of one's own ideas and views that constitutes the core of argumentation in the discursive style that binds the contents of the decision with the most optimal set of particular components of operative interpretation. Depending on the type of the decision the set may include one's own views leading to the indication of other decisions as well as the advantages of the selected solution.

The argumentative content described above as well as the styles of justification additionally map onto the type of recipient of the justification. The recipients constitute a broader catalogue of entities than the recipients of the decisions to apply law. There is not enough space in this study to make and develop detailed differentiation and presentation of interrelationships and dependencies between the components, but their existence indicates that indeed each justification must contain different components. The presence of elements of description of the flow of the decision making process and reasoning leading to a decision with particular contents (significant for the parties and recipients of the decision, in particular when they act on their own) leads to the strengthening of the arbitrary style of presentation of arguments and relationships between these arguments. In turn, emphasis placed on the rationalisation of contents indicates the presence of com-

${ }^{24}$ Cf. M. Zirk-Sadowski, Wykładnia i rozumienie prawa w Polsce po akcesji do Unii Europejskiej, [in:] Polska kultura prawna a proces integracji europejskiej, ed. S. Wronkowska, Cracow 2003, pp. 94-96. O uzasadnianiu w administracyjnym typie decydowania por. J. Zimmermann, Motywy decyzji administracyjnej i jej uzasadnienie, Warsaw 1981, p. 80 and further pages, p. 116 and further pages. 
ponents of the discursive style, although it does not totally exclude the arbitrary style of argumentation. However, it refers it to different dimensions, depending on the type of the decision and the decision maker, the level of difficulty of the case or on the novelty of the case (which can be of interest for the legal doctrine). It is further enhanced if the justifications relate to published decisions of courts of highest instance, in particular decisions made by full court (resolutions) which implies the decision's abstract character. Situations positioned in between these two extremes may lead to a definition of scales of arbitrariness and discursiveness in the context of descriptive components and components that rationalise the decision and the process. Also, such scales will depend on how the decision maker perceives the set of direct and indirect recipients of the decision, and what the set is like in reality.

Apart from the relative statements presented above, the potential for improvement residing in the contents of the justification seems to be significant. It consists in the fundamental alignment of the arguments presented in the justification with the reasoning and activities taken within the decision making process. On the one hand, the components of the justification that refer to the contents of the decision should be subject mainly to rationalisation, also when it comes to the indication of the consequences of making the decision. In turn, rationalisation of reasoning and activities are combined with the description of the mode in which they appear in the process and decide upon the course and outcome of the process. Even if we cannot require and expect a "faithful" description that in reality would weaken the argumentative value of the justification, and if a component of the justification were a list of all doubts and realised "weak points" of the argumentation, certainly the requirement of compliance/alignment assumes a lack of purposeful distortion of the description. Here, too, it is possible to establish scales that will encompass the detailed relations.

\section{FINAL REMARKS}

The decision making model of the process of application of law that absorbs the operative interpretation in the form of both reasoning and activities taken during the process as well as arguments presented in the justification of the decision to apply law may indicate the interpretation's universal dimension and particular dimension, dependent on the given factors that differentiate the decision making processes, including above all the type of application of law.

The basic universal components of the model include:

- accepting the assumption of the occurrence of operative interpretation in each decision making process (which means negation of the clara non sunt interpretanda principle), with the process understood broadly (in its basic and extended version) and including the control and executive phase, 
- realising the basic characteristics of operative interpretation, including most of all, its decision making context, situationality, certainty but also limited scope of outcome of the interpretation,

- distinguishing between reasoning and activities that include validation and reconstruction findings and the special "phases", including pre-reconstruction intuitions and post-reconstruction reduction,

- presentation of interpretative reasoning and activities in the form of arguments in the justification of the decision, with the assumption of fundamental alignment of arguments within the rationalisation of the decision.

The following are the main particular components of the decision making model (relative to the type of the decision making model):

- diversity of relations between particular sources of reconstruction of the norm (regulations, decisions, non-legal criteria) within validation findings,

- diversity of relations between particular principles of reconstruction of the normative basis of the decision (linguistic, systemic, purposeful, functional, axiological),

- diversity of types and sources leading to diversity of decision making discretion in application of law,

- presence of political goals and policies of application of law within the decision making processes of the administrative type,

- diversity of justification styles, associated with the content of descriptive components and components that rationalise the contents of the decision and its process, and with the openness of the presented arguments.

The attributes of the particular types of application of law (basic and particular) modify equally all the indicated particular examples. This means that it is still indispensable to discern both the shared attributes and the differences within the model of decision making under construction. To a certain extent, this will be the subject of part 2 of this collection of articles.

\section{LITERATURE}

Harczuk J., Uzgadnianie w stosowaniu krajowego prawa publicznego, Lublin 2009 (unpublished $\mathrm{PhD}$ dissertation).

Jaśkowska M., Uznanie administracyjne w orzecznictwie sąów administracyjnych, „Zeszyty Naukowe Sądownictwa Administracyjnego" 2010, No. 5-6.

Kalisz A., Zienkiewicz A., Mediacja sądowa i pozasądowa. Zarys wykładu, Warsaw 2009.

Kmieciak Z., Mediacja i koncyliacja w prawie administracyjnym, Cracow 2004.

Lande J., Studia z filozofii prawa, Warsaw 1959.

Lang W., Wróblewski J., Zawadzki S., Teoria państwa i prawa, Warsaw 1979.

Leszczyński L., Orzekanie przez sądy administracyjne a kontrola wykładni prawa, „Zeszyty Naukowe Sądownictwa Administracyjnego" 2010, No. 5-6. 
Leszczyński L., Wykładnia operatywna (podstawowe właściwości), „Państwo i Prawo” 2009, №. 6. Leszczyński L., Zagadnienia teorii stosowania prawa. Doktryna i tezy orzecznictwa, Cracow 2000. Petrażycki L., Wstęp do nauki polityki prawa, Warsaw 1968.

Petrażycki L., Wstęp do nauki prawa i moralności, Warsaw 1959.

Podgórecki A., Założenia polityki prawa, Warsaw 1957.

Wróblewski J., Sądowe stosowanie prawa, Warsaw 1988.

Zieliński M., Poznanie sądowe - poznanie naukowe, Poznań 1979.

Zieliński M., Wybrane zagadnienia wykładni prawa, „Państwo i Prawo” 2009, No. 6.

Ziembiński Z., Problemy podstawowe prawoznawstwa, Warsaw 1980.

Zimmermann J., Motywy decyzji administracyjnej i jej uzasadnienie, Warsaw 1981.

Zirk-Sadowski M., Wykładnia i rozumienie prawa w Polsce po akcesji do Unii Europejskiej, [in:]

Polska kultura prawna a proces integracji europejskiej, ed. S. Wronkowska, Cracow 2003.

\section{SUMMARY}

This article links the types of application of law present in the legal theory with the relevant decision making model, constructed on the basis of two main types: the judicial and the administrative types. However, the model also takes into account the attributes of two subtypes: the mediation and managerial subtypes. The attributes that differentiate the types are associated with the subject, the mode of the process, the shape and contents of the decision, the types of control as well as decision making discretion. The decision making model that applies for all the types referred to above focuses on discerning the preparatory phase which includes fact finding and operative interpretation (in the broad validation-derivative approach) and phases of making the decision to apply law (with the decision divided into the decision that qualifies the factual state and the decision that defines the consequences of the qualification), along with its justification that plays a highly significant communication and argumentation role. The holistic model of the process of application of law ought to also include the potential control phase and execution phase, both of which also, as a rule, constitute separate decision making processes. The following are the basic detailed components of the model, applicable across all types of application of law: making the assumption on the existence of operative interpretation in each decision making process (i.e. negation of the clara non sunt interpretanda principle); differentiation of reasoning and activities that include validation and reconstruction findings as well as post-reconstruction reduction and presentation of reasoning and interpretative activities as arguments justifying the decision, leading to its rationalisation. The following are the main particular components of the decision making model (relative to the type of the decision making model): diversity of relations between particular sources of reconstruction of the norm (regulations, decisions, non-legal criteria) within validation findings; diversity of relations between particular principles of reconstruction of the normative basis of the decision (linguistic, systemic, purposeful, functional, axiological); diversity of types and sources leading to diversity of decision making discretion in application of law; presence of political goals and policies of application of law within the decision making processes of the administrative type, and diversity of justification styles, associated with the content of descriptive components and components that rationalise the contents of the decision and its process, and with the openness of the presented arguments. An extensive analysis of the above-mentioned universal components and differentiators will be the subject of part 2 of this collection of articles. 


\section{STRESZCZENIE}

Model procesu decyzyjnego w sądowym i administracyjnym typie stosowania prawa koncentruje się na wyróżnieniu fazy przygotowawczej. W jej ramach podejmuje się ustalenie stanu faktycznego i wykładnię operatywną (w szerokim ujęciu - walidacyjno-derywacyjnym) oraz fazy podejmowania decyzji stosowania prawa, włącznie z jej uzasadnieniem. Decyzja ta kwalifikuje stan faktyczny i ustala konsekwencje tej kwalifikacji. Uzasadnienie decyzji pełni funkcję komunikacyjną i argumentacyjną. Model całościowy procesu powinien też objąć potencjalną fazę kontrolną oraz fazę egzekucyjną, które co do zasady mogą być traktowane jako odrębne procesy decyzyjne, sprzężone przyczynowo-skutkowo z zasadniczym procesem kończącym się wydaniem decyzji stosowania prawa. Obok uniwersalnych składników tego modelu (takich jak: właściwości wykładni operatywnej; występowanie rozumowań i czynności, obejmujących ustalenia walidacyjne i rekonstrukcyjne oraz szczególne fazy obejmujące intuicję i redukcję decyzyjną), należy także dostrzec występowanie składników różniących poszczególne typy stosowania prawa. Do tych ostatnich należą m.in.: różnorodność relacji między poszczególnymi źródłami rekonstrukcji normy (przepisy prawne, decyzje stosowania prawa, otwarte kryteria pozaprawne); różnorodność relacji między poszczególnymi regułami wykładni (językowymi, systemowymi, celowościowymi, funkcjonalnymi, aksjologicznymi); różnorodność rodzajów, źródeł i zakresów luzów decyzyjnych stosowania prawa; obecność albo nieobecność celów politycznych i polityki stosowania prawa w procesach decyzyjnych, a także różnorodność stylów uzasadniania decyzji. 